\title{
Bacteroides graminisolvens sp. nov., a xylanolytic anaerobe isolated from a methanogenic reactor treating cattle waste
}

Correspondence
Atsuko Ueki
uatsuko@tds1.tr.yamagata-u.ac.jp

\author{
Tomomi Nishiyama, ${ }^{1}$ Atsuko Ueki, ${ }^{1}$ Nobuo Kaku, ${ }^{1}$ Kazuya Watanabe ${ }^{2}$ \\ and Katsuji Ueki ${ }^{1}$
${ }^{1}$ Faculty of Agriculture, Yamagata University, 1-23 Wakaba-machi, Tsuruoka 997-8555, Japan
${ }^{2}$ Exploratory Research for Advanced Technology (ERATO), JST, 7-3-1 Hongo, Bunkyo-ku, Tokyo \\ 113-8656, Japan
}

\begin{abstract}
A strictly anaerobic bacterial strain, designated $\mathrm{XDT}-1^{\top}$, was isolated from plant residue from a methanogenic reactor treating waste from cattle farms. Cells of the strain were Gram-negative, non-motile, non-spore-forming rods. Haemin was required for growth. The strain utilized xylan as well as various sugars including arabinose, xylose, glucose, mannose, cellobiose, raffinose, starch and pectin. The strain produced acetate, propionate and succinate from saccharides in the presence of haemin. The optimum $\mathrm{pH}$ for growth was approximately 7.2 and the optimum growth temperature was $30-35{ }^{\circ} \mathrm{C}$. The strain was sensitive to bile. The major cellular fatty acids of the strain were anteiso- $\mathrm{C}_{15: 0}$ and iso- $\mathrm{C}_{17: 0} 3-\mathrm{OH}, \mathrm{MK}-10\left(\mathrm{H}_{0}\right)$ was the major respiratory quinone and the genomic DNA G $+\mathrm{C}$ content was $38.0 \mathrm{~mol} \%$. Phylogenetic analysis based on 16S rRNA gene sequences placed the strain in the phylum Bacteroidetes. The closest phylogenetic neighbour of strain XDT- $1^{\top}$ was Bacteroides ovatus NCTC $11153^{\top}$, with a $16 \mathrm{~S}$ rRNA gene sequence similarity of $94.2 \%$. On the basis of data from the phylogenetic, physiological and chemotaxonomic analyses, strain XDT- $1^{\top}$ represents a novel species of the genus Bacteroides, for which the name Bacteroides graminisolvens sp. nov. is proposed. The type strain is XDT-1 ${ }^{\top}$ $\left(=\mathrm{JCM} 15093^{\top}=\right.$ DSM $\left.19988^{\top}\right)$.
\end{abstract}

The Bacteroides-Prevotella group consists mainly of species derived from human faecal and oral sources as well as other samples from mammalian organs such as the rumen (Holdeman et al., 1984; Paster et al., 1994; Shah \& Collins, 1989). Although bacterial clones affiliated with the group have often been detected, as dominant components, from methanogenic reactors (Chouari et al., 2005; Godon et al., 1997; Levén et al., 2007), the function of the group in the anaerobic degradation of organic matter in the methanogenic process remains to be clarified. Some Bacteroides species isolated from human faecal samples have been investigated as important decomposers of hemicellulose or xylan (Chassard et al., 2007, 2008; Hayashi et al., 2005; Hespell \& Whitehead, 1990; Hopkins et al., 2003). As hemicellulose and cellulose are the main components (30$40 \%$ ) of the plant cell wall, their concomitant decomposition is a key reaction for the effective methanogenic fermentation of waste that contains plant material (Collins et al., 2005). In this study, we describe a novel xylanolytic bacterial strain, affiliated with the genus Bacteroides, isolated from a plant-residue sample (mainly rice straw)

The GenBank/EMBL/DDBJ accession number for the 16S rRNA gene sequence of strain $\mathrm{XDT-1}{ }^{\top}$ is $\mathrm{AB} 363973$. from a methanogenic reactor treating waste from cattle farms.

Strain $\mathrm{XDT}-1^{\mathrm{T}}$ was isolated from a sample of rice-straw residue obtained from a methanogenic reactor treating waste collected from cattle farms (up to 1000 cattle in total) in Betsukai-machi in Hokkaido, Japan. The reactor was of the vertical cylindrical type $\left(1500 \mathrm{~m}^{3}\right)$ and was operated at $35{ }^{\circ} \mathrm{C}$. Rice straw used as matting at the cattle farms, containing cattle faeces and urine, was thrown into the reactors and treated as waste (Ueki et al., 2008).

Strain $\mathrm{XDT}-1^{\mathrm{T}}$ was cultivated anaerobically at $30{ }^{\circ} \mathrm{C}$ (unless indicated otherwise) by using peptone/yeast extract (PY) medium (10 g peptone and $5 \mathrm{~g}$ yeast extract $\mathrm{l}^{-1}$, respectively) as a basal medium, with $\mathrm{O}_{2}$-free mixed gas $\left(\mathrm{N}_{2} / \mathrm{CO}_{2}, 95: 5\right)$ as the headspace, as described by Ueki et al. (2006a). PY medium supplemented with $0.25 \mathrm{~g}$ each of glucose, cellobiose, maltose and soluble starch $1^{-1}$ as well as $15 \mathrm{~g}_{\text {agar }} \mathrm{l}^{-1}$ (Difco) was designated PY4S agar and used for maintenance of the strain in agar slants. For enrichment culture and the isolation of xylanolytic bacteria, the concentrations of both peptone and yeast extract in the basal medium were decreased to one-tenth of those in PY medium (1/10PY medium) (Nishiyama et al., 2009). PY 
liquid medium supplemented with haemin (at a final concentration of $5 \mathrm{mg} \mathrm{l}^{-1}$ ) (Holdeman et al., 1977) (PYH medium) and $10 \mathrm{~g} g l u c o s e ~^{-1}$ (PYHG medium) was used for cultivation of the strain for various physiological tests and chemotaxonomic analyses of the cells, unless otherwise stated (Ueki et al., 2006b). In addition to haemin, a Bvitamin mixture $\left(10 \mathrm{ml} \mathrm{l}^{-1}\right)$ was added to PYH medium (PYHV medium) for cultivation, as described below. The composition of the B-vitamin mixture used was as follows $\left(100 \mathrm{ml}^{-1}\right)$ : $0.1 \mathrm{mg}$ biotin, $0.1 \mathrm{mg}$ cyanocobalamin (cobalamin or vitamin $\mathrm{B}_{12}$ ), $0.3 \mathrm{mg}$-aminobenzoic acid, $0.5 \mathrm{mg}$ folic acid, $0.5 \mathrm{mg}$ thiamine hydrochloride, $0.5 \mathrm{mg}$ riboflavin and $1.5 \mathrm{mg}$ pyridoxine hydrochloride (Akasaka et al., 2004). The same concentration of cobalamin was used when it was added to the medium as the sole vitamin. Media were usually adjusted to pH 7.2 with $1 \mathrm{M} \mathrm{NaOH}$. Growth in liquid medium was monitored by recording changes in $\mathrm{OD}_{660}$.

Anaerobic sludge samples obtained from the reactor were filtered through a mesh ( $2 \mathrm{~mm}$ pore size) and plant residue remaining on the mesh was collected. The plant-residue samples obtained were washed several times with sterile, anoxic diluent and homogenized in a Waring blender (10 000 r.p.m. for $10 \mathrm{~min}$ ) under $\mathrm{N}_{2}$ (Kaku et al., 2000). The homogenized samples were successively diluted anaerobically and the enrichment culture was started by inoculating $1 \mathrm{ml}$ from 10 -fold diluted samples $\left(10^{-4}\right.$ $\left.10^{-6}\right)$ into $9 \mathrm{ml} 1 / 10 \mathrm{PY}-\mathrm{x}$ liquid medium (1/10PY medium containing birch-wood xylan at $\left.5 \mathrm{~g} \mathrm{l}^{-1}\right)$. After incubation for approximately 1 week, $1 \mathrm{ml}$ culture was transferred to $9 \mathrm{ml}$ fresh 1/10PY-x medium. Growth of xylanolytic bacteria in the enrichment culture was confirmed by a decrease in the $\mathrm{pH}$ of the medium relative to culture without xylan (1/10PY medium). After several subcultures of the xylanolytic enrichment, the diluted enrichment cultures were inoculated to anaerobic roll tubes using 1/10PY-x agar medium, and some colonies were picked after incubation for 1 week. Strain XDT- $1^{\mathrm{T}}$ was finally obtained, from among isolates that included non-xylanolytic, Gram-positive bacteria, after purification using the anaerobic roll-tube method (Hungate, 1966). Strain XDT$1^{\mathrm{T}}$ was isolated from the enrichment culture initially inoculated with a $10^{-5}$-diluted sample of homogenized plant residue.

Growth of strain $\mathrm{XDT}-1^{\mathrm{T}}$ under air was investigated as described previously (Ueki et al., 2008). Spore formation was assessed by observing cells after Gram-staining as well as by means of phase-contrast microscopy. Catalase activity was determined as described previously (Ueki et al., 2008). Oxidase and nitrate-reducing activities were determined according to the methods described by Akasaka et al. (2003b). The utilization of various carbon sources was tested in PYH liquid medium supplemented with each substrate at either $10 \mathrm{~g} \mathrm{l}^{-1}$ (for sugars and sugar alcohols) or $30 \mathrm{mM}$ (for organic acids). The utilization of each substrate was determined by measuring growth $\left(\right.$ as $\left.\mathrm{OD}_{660}\right)$ as well as by determining changes in the $\mathrm{pH}$ of the medium after cultivation. Bile sensitivity was determined by adding Bacto oxgall (Difco) $(0.1-2 \%$, w/v) or bile salts (Oxoid) $(0.1-0.5 \%, w / v)$ to PYHG medium. Fermentation products were analysed by means of GC or HPLC, as described previously (Ueki et al., 1986; Akasaka et al., 2003a). Other characterizations were performed according to the methods described by Holdeman et al. (1977).

Whole-cell fatty acids were converted to methyl esters according to the method of Miller (1982) and were analysed using a gas chromatograph (Hewlett Packard model Hp6890 or Hitachi model G-3000) equipped with an HP Ultra 2 column. Whole-cell fatty acids were identified from equivalent chain-lengths (Miyagawa et al., 1979) according to the protocol of TechnoSuruga (Moore et al., 1994). Isoprenoid quinones were extracted as described by Komagata \& Suzuki (1987) and analysed using a mass spectrometer (JMS-SX102A; JEOL). Genomic DNA extracted according to the method described by Akasaka et al. (2003b) was digested with P1 nuclease by using a Yamasa GC kit (Yamasa Shoyu) and its DNA G + C content was measured by means of HPLC (L-7400; Hitachi) equipped with a $\mu$ Bondapak C18 column $(3.9 \times 300 \mathrm{~mm}$; Waters $)$.

DNA was extracted from cells as described previously (Akasaka et al., 2003b). The almost-complete 16S rRNA gene was PCR-amplified using primers $27 \mathrm{f}$ and $1546 \mathrm{r}$. The PCR-amplified 16S rRNA gene was sequenced using an ABI Prism BigDye Terminator cycle sequencing ready reaction kit and an ABI Prism 3730 automatic DNA sequencer (Applied Biosystems). Multiple alignments of the sequence with reference sequences in GenBank were performed with the BLAST program (Altschul et al., 1997). A phylogenetic tree was constructed with the neighbourjoining method (Saitou \& Nei, 1987) by using the CLUSTAL W program (Thompson et al., 1994). All gaps and unidentified base positions in the alignments were excluded before sequence assembly.

Cells of strain XDT- $1^{\mathrm{T}}$ were Gram-negative rods, usually $0.4-0.6 \mu \mathrm{m}$ wide and $1.2-4.5 \mu \mathrm{m}$ long. Rather long cells often occurred (Fig. 1). Under phase-contrast microscopy, cells were observed to be non-motile. The strain formed very thin colonies with smooth surfaces on PY4S agar and had a pearl-like iridescence under light. The strain could not grow under aerobic conditions. Spore formation was not observed.

Strain XDT- $1^{\mathrm{T}}$ grew slowly $\left(\mu=0.14 \mathrm{~h}^{-1}\right)$ in PYG liquid medium (without haemin and the B-vitamin mixture); the addition of haemin to the medium (PYHG) stimulated growth considerably $\left(\mu=0.39 \mathrm{~h}^{-1}\right)$. Although addition of the vitamin mixture alone to PYG medium did not affect the growth rate $\left(\mu=0.13 \mathrm{~h}^{-1}\right)$, the addition of a vitamin mixture or cobalamin to PYHG liquid medium (PYHVG medium) slightly enhanced growth $\left(\mu=0.40-0.41 \mathrm{~h}^{-1}\right)$.

Catalase activity was not detected in cells grown in PY4S agar slants or in PYG liquid medium as well as cells grown 


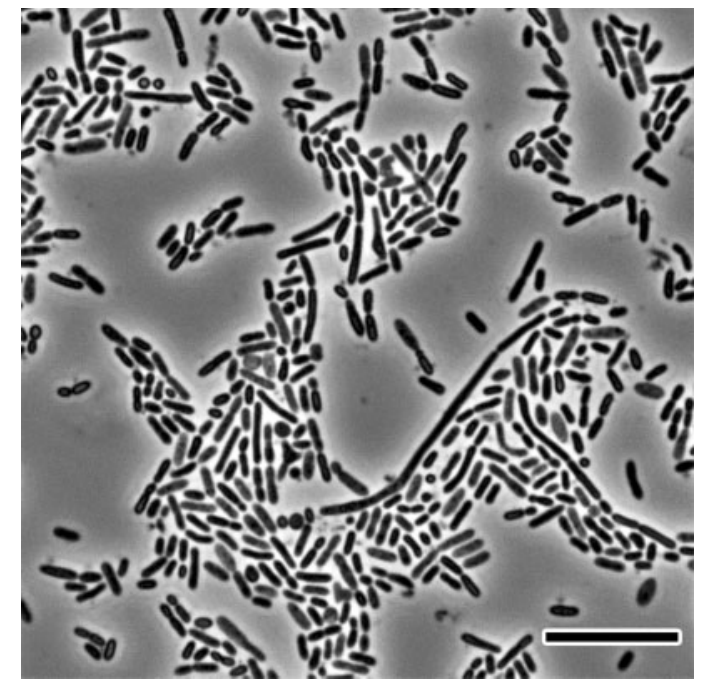

Fig. 1. Phase-contrast photomicrograph of cells of strain $X D T-1^{\top}$ grown anaerobically on an agar slant of PY4S medium. Bar, $10 \mu \mathrm{m}$.

in PYHG medium. Oxidase activity was not detected. The strain utilized various sugars in addition to xylan and glucose (see the species description and Table 1). Substrates that were not utilized are also listed in the species description. The strain produced acetate $\left(1.9 \mathrm{mmol} \mathrm{l}^{-1}\right)$, propionate $\left(1.4 \mathrm{mmol} \mathrm{l}^{-1}\right)$ and succinate $\left(4.3 \mathrm{mmol} \mathrm{l}^{-1}\right)$ from glucose (PYHG medium). Without haemin (PYG medium), a small amount of lactate was produced in addition to acetate, while propionate and succinate were not detected. A small amount of pyruvate was sometimes formed in PYHG medium. When grown in the presence of the vitamin mixture as well as haemin (PYHVG medium), propionate production was enhanced and there was a concomitant decrease in succinate production (acetate, $1.5 \mathrm{mmol} \mathrm{l}^{-1}$; propionate, $3.6 \mathrm{mmol} \mathrm{l}^{-1}$; succinate, $2.9 \mathrm{mmol} \mathrm{l}^{-1}$ ). The final $\mathrm{pH}$ was 4.9. Almost the same concentrations of products were formed from xylose in $\mathrm{PYH}$ medium. When growth was performed on PYH medium containing xylan $\left(5 \mathrm{gl}^{-1}\right)$, propionate was the predominant product $\left(5.8 \mathrm{mmol} \mathrm{l}^{-1}\right)$, with smaller concentrations of acetate $\left(3.4 \mathrm{mmol} \mathrm{l}^{-1}\right)$ and succinate $\left(2.0 \mathrm{mmol} \mathrm{l}^{-1}\right)$. In the presence of the vitamin mixture as well as haemin (PYHV medium), propionate production from xylan increased to $10.3 \mathrm{mmol}^{-1}$, with acetate and succinate as minor products $\left(3.1\right.$ and $1.3 \mathrm{mmol} \mathrm{l}^{-1}$, respectively), after cultivation for 2 days. The final $\mathrm{pH}$ with xylan was 5.2-5.3. Almost the same concentrations of products were detected when growth was performed in the medium containing $10 \mathrm{~g}$ xylan $\mathrm{l}^{-1}$, even after 7 days incubation. The decrease in $\mathrm{pH}$ of the medium should limit xylan utilization. The vitamin mixture and cobalamin showed the same effect on the fermentation products; thus, cobalamin in the vitamin mixture appeared to stimulate propionate production.

The optimum $\mathrm{pH}$ was $7.2\left(\mu=0.39 \mathrm{~h}^{-1}\right)$ and the $\mathrm{pH}$ range for growth was 6.1-8.2. The strain did not grow at an initial $\mathrm{pH}$ of 5.0 or 8.7. The growth temperature range was 5$40{ }^{\circ} \mathrm{C}$, with an optimum at $30-35{ }^{\circ} \mathrm{C}\left(\mu=0.39-0.41 \mathrm{~h}^{-1}\right)$. Although the growth rate at $40{ }^{\circ} \mathrm{C}\left(\mu=0.45 \mathrm{~h}^{-1}\right)$ was

Table 1. Characteristics that serve to differentiate strain $\mathrm{XDT}-1^{\top}$ from related species of the genus Bacteroides

Strains/species: 1 , strain XDT- ${ }^{\mathrm{T}}$; 2, B. ovatus; 3, B. thetaiotaomicron; 4, B. xylanisolvens DSM $18836^{\mathrm{T}}$. Data for reference taxa were taken from Holdeman et al. (1984) and Chassard et al. (2008). +, Positive; -, negative; v, variable, depending on strain; ND, no data available.

\begin{tabular}{|c|c|c|c|c|}
\hline Characteristic & 1 & 2 & 3 & 4 \\
\hline Isolation source & Methanogenic reactor & Human faeces & Human faeces & Human faeces \\
\hline Optimum growth temperature $\left({ }^{\circ} \mathrm{C}\right)$ & 35 & 37 & 37 & 38 \\
\hline Predominant quinone(s) & MK-10 & MK-10, MK-11 & MK-10, MK-11 & $\mathrm{ND}$ \\
\hline Catalase activity & - & $\mathrm{V}$ & $\mathrm{V}$ & - \\
\hline Growth in bile & - & + & + & $\mathrm{ND}$ \\
\hline Products from glucose ${ }^{\star}$ & A, $P,(s)$ & $\mathrm{A}, \mathrm{S},(\mathrm{P})$ & $\mathrm{A}, \mathrm{S},(\mathrm{P})$ & A, $P, S$ \\
\hline \multicolumn{5}{|l|}{ Acid production from: } \\
\hline Trehalose & - & + & + & + \\
\hline Melezitose & - & - & - & + \\
\hline Starch & + & + & + & - \\
\hline Xylan & + & + & - & + \\
\hline Salicin & + & + & - & + \\
\hline
\end{tabular}

${ }^{\star}$ A, Acetate; $\mathrm{P}$, propionate; $\mathrm{s}$, succinate. Minor products are given in parentheses. 
higher than that at $35{ }^{\circ} \mathrm{C}$, the maximum $\mathrm{OD}_{660}$ of the culture was lower than that reached at $35{ }^{\circ} \mathrm{C}$ and the $\mathrm{OD}_{660}$ soon declined, indicating cell lysis. The strain even grew at $5{ }^{\circ} \mathrm{C}$, albeit at a rather low growth rate $\left(\mu=0.006 \mathrm{~h}^{-1}\right)$. The $\mathrm{NaCl}$ concentration range for growth was $0-4 \%(\mathrm{w} / \mathrm{v})$ in PYHG medium, with an optimum at $0 \%(\mathrm{w} / \mathrm{v}) \mathrm{NaCl}$. Aesculin and starch were hydrolysed, but gelatin was not hydrolysed. Nitrate-reducing and urease activities were not detected. The strain did not grow in the presence of $2 \%$ $(\mathrm{w} / \mathrm{v})$ Bacto oxgall or $0.1 \%(\mathrm{w} / \mathrm{v})$ bile acids; growth was strongly inhibited even in the presence of $0.1 \%(\mathrm{w} / \mathrm{v})$ Bacto oxgall. The strain did not produce indole or sulfide.

The major whole-cell fatty acids of strain $\mathrm{XDT}-1^{\mathrm{T}}$ were anteiso- $\mathrm{C}_{15: 0}(33.4 \%)$, iso- $\mathrm{C}_{17: 0} 3-\mathrm{OH}(20.0 \%)$, iso- $\mathrm{C}_{15: 0}$ $(8.9 \%)$ and anteiso- $\mathrm{C}_{13: 0}(7.0 \%)$. Minor fatty acids included iso- $\mathrm{C}_{13: 0}(4.9 \%), \mathrm{C}_{15: 0}(4.0 \%)$, anteiso- $\mathrm{C}_{17: 0}$ $3-\mathrm{OH}(3.6 \%), \mathrm{C}_{16: 0}(3.0 \%)$, iso- $\mathrm{C}_{14: 0}(2.0 \%), \mathrm{C}_{14: 0}$ (1.9\%), iso- $\mathrm{C}_{16: 0}(1.5 \%), \mathrm{C}_{16: 0} \quad 3-\mathrm{OH} \quad(1.3 \%)$ and anteiso- $\mathrm{C}_{17: 0}(1.2 \%)$. MK-10 $\left(\mathrm{H}_{0}\right)$ was the major respiratory quinone and the genomic DNA $\mathrm{G}+\mathrm{C}$ content was $38.0 \mathrm{~mol} \%$.

Phylogenetic analysis based on the $16 \mathrm{~S}$ rRNA gene sequence placed the strain in the phylum Bacteroidetes. The closest relative of strain XDT- $1^{\mathrm{T}}$ was Bacteroides ovatus NCTC $11153^{\mathrm{T}}$, with $16 \mathrm{~S}$ rRNA gene sequence similarity of $94.2 \%$. The next closest relatives were Bacteroides thetaiotaomicron ATCC $29148^{\mathrm{T}}$ ) (similarity of $94.0 \%$ ) and Bacteroides xylanisolvens DSM $18836^{\mathrm{T}} \quad(93.6 \%)$. Bacteroides eggerthii NCTC $11155^{\mathrm{T}}$ (93.3\%), Bacteroides acidifaciens JCM $10556^{\mathrm{T}}$ (93.3\%), Bacteroides caccae ATCC $43185^{\mathrm{T}}(93.1 \%)$, Bacteroides finegoldii JCM $13345^{\mathrm{T}}$ (92.7\%) and Bacteroides fragilis ATCC $25285^{\mathrm{T}}$ (92.5\%) were the next most closely related members of the genus Bacteroides.

Of the few xylan-decomposing species that belong to the genus Bacteroides, B. ovatus is one that has been investigated extensively with regard to its xylanase system (Cooper et al., 1985; Hopkins et al., 2003). B. xylanisolvens, isolated from human faeces, was described quite recently as a xylanolytic bacterium (Chassard et al., 2008). In addition, a subspecies of $B$. fragilis from human faecal samples is also known to be xylanolytic (Hespell \& Whitehead, 1990; Hopkins et al., 2003) and B. eggerthii was described as producing acids from xylan (Holdeman et al., 1984). Furthermore, recent reports have indicated that Bacteroides intestinalis and Bacteroides dorei (Bakir et al., 2006a, b), both of which were isolated from human faeces, have the ability to decompose hemicellulose (Chassard et al., 2007). Thus, the phylogenetic placement of strain XDT- $1^{\mathrm{T}}$ is close to known xylanolytic species of the genus Bacteroides (Fig. 2).

Hemicellulose and xylan are the predominant components of plant biomass, and thus their decomposition is an important function of fermentative bacteria in anaerobic environments containing plant material. Recent reports have indicated the importance of species from the genus Bacteroides in the decomposition of hemicellulose in the

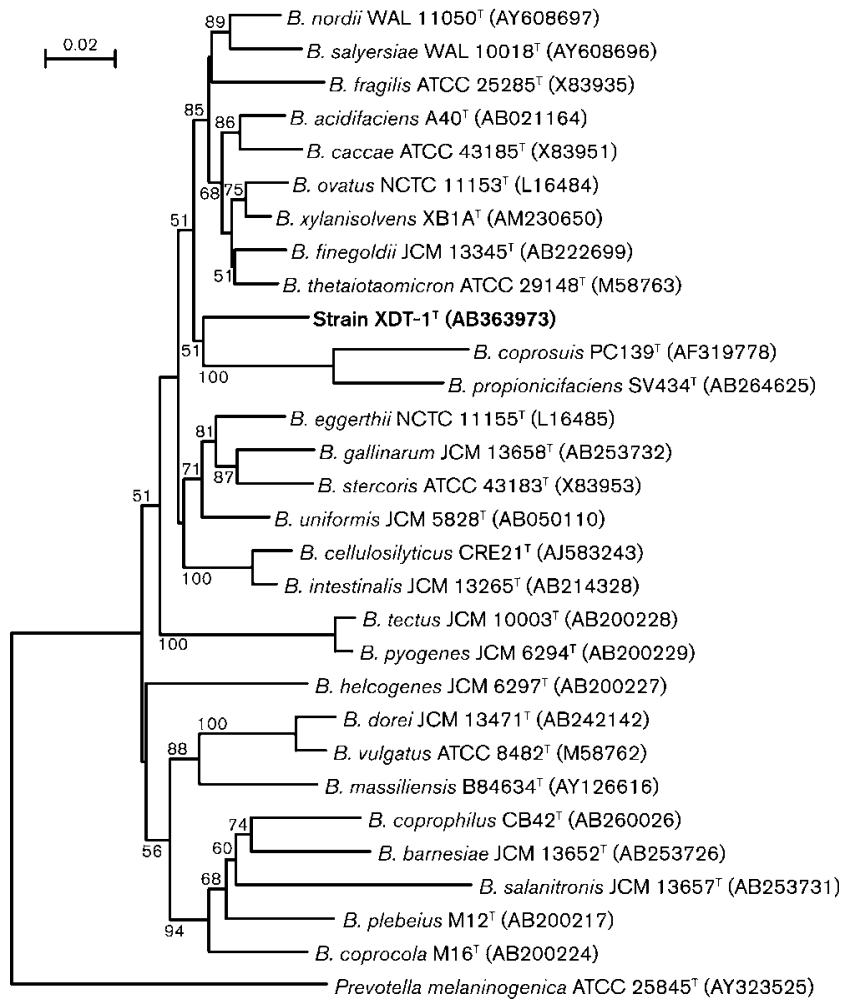

Fig. 2. Neighbour-joining phylogenetic tree, based on $16 \mathrm{~S}$ rRNA gene sequences, showing the position of strain XDT- $1^{\top}$. Bootstrap percentages (based on 1000 replications) above $50 \%$ are shown at branch nodes. The sequence of Prevotella melaninogenica ATCC $25845^{\top}$ was used as the outgroup. Bar, $2 \%$ estimated difference in nucleotide sequences.

human intestine. Hopkins et al. (2003) reported that xylan breakdown by human intestinal microbes resulted in increased propionate formation relative to that formed from starch breakdown (which was associated with the production of acetate and butyrate). Strain XDT- $1^{\mathrm{T}}$ produced acetate and propionate, with smaller amounts of succinate, in the presence of the B-vitamin mixture or cobalamin from various saccharides. Furthermore, more propionate and less succinate were produced from xylan than were produced from glucose or xylose. The data are consistent with the results of Hopkins et al. (2003) and suggest that hemicellulose decomposition is an important function of the Bacteroides species in anaerobic environments and that this may cause increases in propionate production in such habitats.

Some characteristics of strain $\mathrm{XDT}-1^{\mathrm{T}}$ and its closest relatives are compared in Table 1. Only a few species in the genus Bacteroides have been isolated from sources other than mammalian samples (Ueki et al. 2008; Whitehead et al., 2005) and all of the closest relatives of strain XDT- $1^{\mathrm{T}}$ were also derived from human faeces. Although XDT- $1^{\mathrm{T}}$ shares common morphological, physiological and chemotaxonomic characteristics with Bacteroides species isolated 
from mammalian samples, the strain has some features that serve to differentiate it from its relatives. Although $B$. ovatus and $B$. thetaiotaomicron usually have catalase activity (Holdeman et al., 1984), we did not detect it in strain XDT- $1^{\mathrm{T}}$ despite careful examination (Ueki et al., 2008; Wilkins et al., 1978). Bile resistance is one of the characteristics specific to Bacteroides species, yet our strain was highly sensitive to bile. The strain did not produce indole. B. thetaiotaomicron has been clearly differentiated from B. ovatus on the basis of its inability to ferment xylan (Cooper et al., 1985) and the range of substrates utilized by strain XDT- $1^{\mathrm{T}}$ differed from those of any of the closely related species. The whole-cell fatty acid profile of XDT- $1^{\mathrm{T}}$ was basically consistent with those of Bacteroides species, although the percentages of some whole-cell fatty acids, such as anteiso- $\mathrm{C}_{13: 0}(7.0 \%), \mathrm{C}_{16: 0}(3.0 \%)$ and $\mathrm{C}_{16: 0} 3$ $\mathrm{OH}(1.3 \%)$, were rather different in the novel strain (Miyagawa et al., 1979; Shah \& Collins, 1980).

A haemin requirement is commonly found in Bacteroides species. We recently described three novel species (isolated from plant residue from irrigated rice-field soil as well as a methanogenic reactor) that were related to those in the Bacteroides-Prevotella group. All three species also required haemin for growth (Ueki et al., 2006b, 2007, 2008). These results suggest that bacterial species related to those of the Bacteroides-Prevotella group living in habitats other than the mammalian body also require haemin for growth. A cobalamin requirement was also commonly found in propionate-producing strains of the above-mentioned novel species.

Xylanolytic Bacteroides species such as B. ovatus and B. fragilis are known to be isolated only rarely from human faecal samples when xylan is used as a selective substrate (Wedekind et al., 1988; Chassard et al., 2007). In this study to enrich for xylanolytic bacteria, the peptone and yeast extract concentrations in the medium were reduced to onetenth of those in the normal PY medium. In our experience, higher concentrations of these components in medium used for the enrichment of xylan- or cellulosedecomposing bacteria usually enhanced the growth of fastgrowing proteolytic or aminolytic bacteria, and these bacteria usually outcompeted polysaccharide-decomposing bacteria (Nishiyama et al., 2009). The use of reduced concentrations of peptone and yeast extract should suppress the growth of non-xylanolytic bacteria compared with that produced in the normal PY medium, and thus xylan-decomposing Bacteroides species should be enriched successfully. Furthermore, we used homogenized plant residue as an inoculum for the enrichment. We have previously isolated three novel species belonging to the Bacteroides-Prevotella group from plant residue samples obtained from rice-field soil and a methanogenic reactor, as described above (Ueki et al., 2006b, 2007, 2008). Thus, it seems likely that bacterial species related to those of the Bacteroides-Prevotella group often live on plant residue as decomposers of hemicellulose or other plant material (e.g. pectin) in various anaerobic environments.
On the basis of the data from these phylogenetic, physiological and chemotaxonomic analyses, strain XDT$1^{\mathrm{T}}$ represents a novel species of the genus Bacteroides, for which the name Bacteroides graminisolvens sp. nov. is proposed.

\section{Description of Bacteroides graminiso/vens sp. nov.}

Bacteroides graminisolvens (gra.mi.ni.sol'vens. L. neut. n. gramen grass; L. v. solvere dissolve; N.L. part. adj. graminisolvens grass-dissolving).

Cells are Gram-negative, non-motile, non-spore-forming rods $(0.4-0.6 \mu \mathrm{m}$ wide and $1.2-4.5 \mu \mathrm{m}$ long); some longer cells occur. Produces thin, smooth-surfaced colonies with a pearl-like, iridescent lustre under light. Growth is strongly stimulated by the addition of haemin; cobalamin (vitamin $\mathrm{B}_{12}$ ) slightly enhances growth. Utilizes arabinose, xylose, fructose, galactose, glucose, mannose, cellobiose, lactose, maltose, melibiose, sucrose, raffinose, xylo-oligosaccharides, dextrin, glycogen, starch, pectin, xylan (birch wood), amygdalin and salicin. Ribose, rhamnose, inulin, aesculin and pyruvate are utilized only weakly. In the presence of haemin and cobalamin, acetate and propionate are produced from glucose, along with small amounts of succinate. Propionate is the most abundant product from xylan in the presence of haemin and cobalamin. In the presence of glucose and xylan, the final $\mathrm{pH}$ is 4.9 and 5.2-5.3, respectively. Does not use sorbose, trehalose, melezitose, CM-cellulose, cellulose (filter-paper fragments and ballmilled powder), glycerol, dulcitol, inositol, mannitol, sorbitol, ethanol, fumarate, lactate, malate or succinate. The optimum $\mathrm{pH}$ is 7.2. The growth temperature range is $5-40{ }^{\circ} \mathrm{C}$; the optimum is $30-35{ }^{\circ} \mathrm{C}$. The $\mathrm{NaCl}$ concentration range for growth is $0-4.0 \%(\mathrm{w} / \mathrm{v})$ in PYHG medium; optimum growth in the absence of $\mathrm{NaCl}$. Does not have catalase, oxidase, nitrate-reducing or urease activities. Does not produce hydrogen sulfide or indole. Hydrolyses aesculin and starch, but not gelatin. Sensitive to bile. The major cellular fatty acids are anteiso- $\mathrm{C}_{15: 0}$ and iso- $\mathrm{C}_{17: 0} 3-\mathrm{OH}$ and the major respiratory quinone is MK-10 $\left(\mathrm{H}_{0}\right)$. The genomic DNA G $+\mathrm{C}$ content of the type strain is $38.0 \mathrm{~mol} \%$.

The type strain, XDT $-1^{\mathrm{T}}\left(=\mathrm{JCM} 15093^{\mathrm{T}}=\mathrm{DSM} 19988^{\mathrm{T}}\right)$, was isolated from rice-straw residue in a methanogenic reactor treating waste from cattle farms.

\section{Acknowledgements}

This work was partly supported by a grant-in-aid from the Institute for Fermentation, Osaka, Japan, and also by the Project for Development of Technology for Analysing and Controlling the Mechanism of Biodegrading and Processing supported by the New Energy and Industrial Technology Development Organization (NEDO). We are grateful to Dr T. Hoaki for the sampling of sludge and to Dr K. Takahashi for quinone analysis. 


\section{References}

Akasaka, H., Izawa, T., Ueki, K. \& Ueki, A. (2003a). Phylogeny of numerically abundant culturable anaerobic bacteria associated with degradation of rice plant residue in Japanese paddy field soil. FEMS Microbiol Ecol 43, 149-161.

Akasaka, H., Ueki, A., Hanada, S., Kamagata, Y. \& Ueki, K. (2003b). Propionicimonas paludicola gen. nov., sp. nov., a novel facultatively anaerobic, Gram-positive, propionate-producing bacterium isolated from plant residue in irrigated rice-field soil. Int J Syst Evol Microbiol 53, 1991-1998.

Akasaka, H., Ueki, K. \& Ueki, A. (2004). Effects of plant residue extract and cobalamin on growth and propionate production of Propionicimonas paludicola isolated from plant residue in irrigated rice field soil. Microbes Environ 19, 112-119.

Altschul, S. F., Madden, T. L., Schäffer, A. A., Zhang, J., Zhang, Z., Miller, W. \& Lipman, D. J. (1997). Gapped BLAST and PSI-BLAST: a new generation of protein database search programs. Nucleic Acids Res 25, 3389-3402.

Bakir, M. A., Kitahara, M., Sakamoto, M., Matsumoto, M. \& Benno, Y. (2006a). Bacteroides intestinalis sp. nov., isolated from human faeces. Int J Syst Evol Microbiol 56, 151-154.

Bakir, M. A., Kitahara, M., Sakamoto, M., Matsumoto, M. \& Benno, Y. (2006b). Bacteroides dorei sp. nov., isolated from human faeces. Int J Syst Evol Microbiol 56, 1639-1643.

Chassard, C., Goumy, V., Leclerc, M., Del'homme, C. \& BernalierDonadille, A. (2007). Characterization of the xylan-degrading microbial community from human faeces. FEMS Microbiol Ecol 61, 121-131.

Chassard, C., Delmas, E., Lawson, P. A. \& Bernalier-Donadille, A. (2008). Bacteroides xylanisolvens sp. nov., a xylan-degrading bacterium isolated from human faeces. Int J Syst Evol Microbiol 58, 10081013.

Chouari, R., Le Paslier, D., Daegelen, P., Ginestet, P., Weissenbach, J. \& Sghir, A. (2005). Novel predominant archaeal and bacterial groups revealed by molecular analysis of an anaerobic sludge digester. Environ Microbiol 7, 1104-1115.

Collins, T., Gerday, C. \& Feller, G. (2005). Xylanases, xylanase families and extremophilic xylanases. FEMS Microbiol Rev 29, 3-23.

Cooper, S. W., Pfeiffer, D. G. \& Tally, F. P. (1985). Evaluation of xylan fermentation for the identification of Bacteroides ovatus and Bacteroides thetaiotaomicron. J Clin Microbiol 22, 125-126.

Godon, J.-J., Zumstein, E., Dabert, P., Habouzit, F. \& Moletta, R. (1997). Molecular microbial diversity of an anaerobic digestor as determined by small-subunit rDNA sequence analysis. Appl Environ Microbiol 63, 2802-2813.

Hayashi, H., Abe, T., Sakamoto, M., Ohara, H., Ikemura, T., Sakka, K. \& Benno, Y. (2005). Direct cloning of genes encoding novel xylanases from the human gut. Can J Microbiol 51, 251-259.

Hespell, R. B. \& Whitehead, T. R. (1990). Physiology and genetics of xylan degradation by gastrointestinal tract bacteria. J Dairy Sci 73, 3013-3022.

Holdeman, L. V., Cato, E. P. \& Moore, W. E. C. (1977). Anaerobe Laboratory Manual, 4th edn. Blacksburg, VA: Virginia Polytechnic Institute and State University.

Holdeman, L. V., Kelly, R. W. \& Moore, W. E. C. (1984). Genus I. Bacteroides Castellani and Chalmers 1919, 959. In Bergey's Manual of Systematic Bacteriology, vol. 1, pp. 604-631. Edited by N. R. Krieg \& J. G. Holt. Baltimore: Williams \& Wilkins.

Hopkins, M. J., Englyst, H. N., Macfarlane, S., Furrie, E., Macfarlane, G. T. \& McBain, A. J. (2003). Degradation of cross-linked and non- cross-linked arabinoxylans by the intestinal microbiota in children. Appl Environ Microbiol 69, 6354-6360.

Hungate, R. E. (1966). The Rumen and its Microbes. New York: Academic Press.

Kaku, N., Ueki, A., Fujii, H. \& Ueki, K. (2000). Methanogenic activities on rice roots and plant residue and their contributions to methanogenesis in wetland rice field soil. Soil Biol Biochem 32, 2001-2010.

Komagata, K. \& Suzuki, K. (1987). Lipid and cell-wall analysis in bacterial systematics. Methods Microbiol 19, 161-207.

Levén, L., Eriksson, A. R. B. \& Schnürer, A. (2007). Effect of process temperature on bacterial and archaeal communities in two methanogenic bioreactors treating organic household waste. FEMS Microbiol Ecol 59, 683-693.

Miller, L. T. (1982). Single derivatization method for routine analysis of bacterial whole-cell fatty acid methyl esters, including hydroxyl acids. J Clin Microbiol 16, 584-586.

Miyagawa, E., Azuma, R. \& Suto, E. (1979). Cellular fatty acid composition in Gram-negative obligately anaerobic rods. J Gen Appl Microbiol 25, 41-51.

Moore, L. V. H., Bourne, D. M. \& Moore, W. E. C. (1994). Comparative distribution and taxonomic value of cellular fatty acids in thirty-three genera of anaerobic Gram-negative bacilli. Int J Syst Bacteriol 44, 338347.

Nishiyama, T., Ueki, A., Kaku, N. \& Ueki, K. (2009). Clostridium sufflavum sp. nov., isolated from a methanogenic reactor treating cattle waste. Int J Syst Evol Microbiol 59, 981-986.

Paster, B. J., Dewhirst, F. E., Olsen, I. \& Fraser, G. J. (1994). Phylogeny of Bacteroides, Prevotella, and Porphyromonas spp. and related species. J Bacteriol 176, 725-732.

Saitou, N. \& Nei, M. (1987). The neighbor-joining method: a new method for reconstructing phylogenetic trees. Mol Biol Evol 4, 406-425.

Shah, H. N. \& Collins, D. M. (1980). Fatty acid and isoprenoid quinone composition in the classification of Bacteroides melaninogenicus and related taxa. J Appl Bacteriol 48, 75-87.

Shah, H. N. \& Collins, D. M. (1989). Proposal to restrict the genus Bacteroides (Castellani and Chalmers) to Bacteroides fragilis and closely related species. Int J Syst Bacteriol 39, 85-87.

Thompson, J. D., Higgins, D. G. \& Gibson, T. J. (1994). Clustal W: improving the sensitivity of progressive multiple sequence alignment through sequence weighting, position-specific gap penalties and weight matrix choice. Nucleic Acids Res 22, 4673-4680.

Ueki, A., Matsuda, K. \& Ohtsuki, C. (1986). Sulfate reduction in the anaerobic digestion of animal waste. J Gen Appl Microbiol 32, 111123.

Ueki, A., Akasaka, H., Suzuki, D. \& Ueki, K. (2006a). Paludibacter propionicigenes gen. nov., sp. nov., a novel strictly anaerobic, Gramnegative, propionate-producing bacterium isolated from plant residue in irrigated rice-field soil in Japan. Int J Syst Evol Microbiol 56, 39-44.

Ueki, A., Akasaka, H., Suzuki, D., Hattori, S. \& Ueki, K. (2006b). Xylanibacter oryzae gen. nov., sp. nov., a novel strictly anaerobic, Gram-negative, xylanolytic bacterium isolated from rice-plant residue in flooded rice-field soil in Japan. Int J Syst Evol Microbiol 56, 22152221.

Ueki, A., Akasaka, H., Satoh, A., Suzuki, D. \& Ueki, K. (2007). Prevotella paludivivens sp. nov., a novel strictly anaerobic, Gramnegative, hemicellulose-decomposing bacterium isolated from plant residue and rice roots in irrigated rice-field soil. Int J Syst Evol Microbiol 57, 1803-1809. 
Ueki, A., Abe, K., Kaku, N., Watanabe, K. \& Ueki, K. (2008). Bacteroides propionicifaciens sp. nov., isolated from rice-straw residue in a methanogenic reactor treating waste from cattle farms. Int J Syst Evol Microbiol 58, 346-352.

Wedekind, K. J., Mansfield, H. R. \& Montgomery, L. (1988). Enumeration and isolation of cellulolytic and hemicellulolytic bacteria from human feces. Appl Environ Microbiol 54, 1530-1535.
Whitehead, T. R., Cotta, M. A., Collins, M. D., Falsen, E. \& Lawson, P. A. (2005). Bacteroides coprosuis sp. nov., isolated from swine-manure storage pits. Int J Syst Evol Microbiol 55, 25152518.

Wilkins, T. D., Wagner, D. L., Veltri, B. J., Jr \& Gregory, E. M. (1978). Factors affecting production of catalase by Bacteroides. J Clin Microbiol 8, 553-557. 